\title{
REALITIES OF MOBILE LEARNING TECHNOLOGIES IN FOREIGN LANGUAGE CLASSES
}

\author{
Christina Huhn, Jean-Louis Dassier, \& Shijuan Liu \\ Indiana University of Pennsylvania
}

\begin{abstract}
While it is common to assume that our current undergraduates are digital native who are naturally proficient and expect the use of technology, the research base that supports those assumptions is limited. This is especially true of students in foreign language classes. Much of the national research that has been conducted has not focused on specific subsets of students.

It is important to address this paucity of research, as instructors, textbook publishers, and other stakeholders must make informed decisions regarding the design and development of curriculum and instructional materials. This article reports a study conducted in exploration of the ownership and use of mobile devices by students in foreign language courses. The study used survey methodology and focus group protocols to investigate what technological devices students have and use for personal and academic activities. Salient findings include the reaffirmation of the need to maintain appropriate pedagogy in light of the latest and greatest technological developments, distinctions between the use of technology for content consumption versus content production, and a distinct preference for a separation between personal and academic activities among digital natives.
\end{abstract}


Huhn, Dossier, \& Liu

\section{INTRODUCTION}

"Today's digital kids think of information and communications technology (ICT) as something akin to oxygen: they expect it, it's what they breathe, and it's how they live. They use ICT to meet, play, date, and learn. It's an integral part of their social life; it's how they acknowledge each other and form their personal identities." (Brown, 2002)

While statements such as these are commonplace in reference to traditional age undergraduates, one must ask if there is a research base to support such statements, especially in the field of world language learning. In truth, whether students embrace and employ those technologies academically remains under discussion (Caruso \& Salaway, 2008; Dahlstrom, 2012; Dahlstrom \& Bichsel, 2014).

Dahlstrom \& Bichsel (2014) reached several key conclusions in their recent research on undergraduate students and information technology:

- More students own mobile devices now than ever. Smart phone ownership has risen $76 \%$, and $90 \%$ of students surveyed currently own a laptop. Future projections show continued increases in ownership (p. 14). This is further supported by looking at previous research on these topics (Caruso \& Salaway, 2008; Dahlstrom, 2012).

- Students' academic use of technology is widespread but not deep. Students are comfortable with a limited set of technologies and express resistance to the expansion of some technologies, such as social media and e-portfolios (Dahlstrom \& Bichsel, 2014, p. 12).

- Many students use smart phones or tablets for academic purposes, although in-class use remains uncommon. Students are more likely to apply mobile devices to academics when instructors encourage their use in class (Dahlstrom \& Bichsel, 2014, p. 17).

Unlike the above noted research, however, there is a paucity of research on the realities of student use of mobile technologies specific to students learning world languages. Because the dissemination of technology tends to outpace research, discussions of mobile technology have long been and continue to be ongoing (Burston, 2014a, 2014b; Dahlstrom, 2012). While published literature on implementations of technology into world language classes yields a plethora of articles on Mobile Assisted Language Learning (MALL) technologies (See for 
example Chinnery, 2006 and Burston, 2014a, 2014b), more studies are needed to investigate the relationship between ownership of and use of the mobile technologies by world language students. Research on the realities of world language students using mobile technologies can help instructors, textbook publishers, and other stakeholders to make informed decisions in the design and development of curriculum and instructional materials. This project reports a study conducted in exploration of the ownership and use of mobile devices by students in world language courses.

\section{REVIEW OF THE LITERATURE}

From the language labs and repetitive drills of the 1950's and 1960's, through the advent of the internet in the 1990's, to current textbook support websites and activities, technology in world language learning has proven to evolve (Blake 2013; Burston 2014a, 2014b; Chinnery, 2006). The latest generation of smart phones and other mobile technologies, also referred to as MALL and BYOD (Bring Your Own Device) have continued this progression. Technology tends to outpace published research, and Burston (2014a) notes that $45 \%$ of research done on MALL comes from conference presentation sessions, which is notably more than other types of publications.

Each generation of technology brings both benefits and challenges, and it is important to keep our focus on the learner and pedagogy, rather than on the latest and greatest technology (Chinnery, 2006; Salaberry, 2001). Blake (2013) cautions against making assumptions about students' use of technology. Technology varies greatly, and is constantly in flux and evolving; we do not know what kind of technology will confront our students 10 years from now. There tends to be an overly enthusiastic approach to technology as a "new methodology," when in reality the technology must be treated as the medium; the creativity and expertise of a teacher cannot be replaced (Blake, 2013; Burston, 2011).

Prensky (2001) theorizes that today's students think differently. They have grown up with current technology and are, by definition "digital natives." Their brains and thinking patterns, along with their daily habits, have changed. In contrast, the current U.S. educational system was not designed to teach this kind of student. Teachers who are "digital immigrants" and didn't grow up with the same environment as our students need to be aware of their "accent" - a 
pronounced difference in how we approach our world. His research, however, offers no empirical data to support his position, reinforcing the need for continued research.

Additionally, Kennedy, Judd, Churchward, Gray and Krause (2008) note the paucity of research in support of the premises we make about these digital natives. Their survey found that student access (at their Australian institution) was high, but their research was inconclusive on personal versus academic use. They conclude their research with a continued call for more in-depth, qualitative investigation on student technology use.

Ducate and Lomicka (2013) expanded on this idea, and contend that we have shifted from Computer Assisted Language Learning (CALL) to "Mobile Learning" (M-learning) or MALL. As one of the few studies that have investigated student personal versus academic use of mobile devices specific to world language learners, Ducate and Lomicka (2013) had students keep a log of their activities using the iPod Touch or smart phone. An analysis of the student's logs found that intermediate language students took advantage of the technology for personal and academic use, increasing exposure to the target language and culture. Their analysis also found that students used their devices for a variety of activities, both academic and personal. Academically, they used different applications, such as a dictionary, searching, and tweeting, while personally they used Facebook, music searches and apps. The division between personal and academic use was an even split between the types of activities. Further, Ducate and Lomicka (2013) found that while the technology afforded students easy and mobile access to authentic materials, provided students with autonomy and exposure to the target language and culture, and increased opportunities for communication, it was at times difficult to discern personal versus academic use. In sum, this research illustrates the potential that mobile technology can have. One student summed up their use of technology by saying "I could think about the language anywhere and anytime." (Ducate \& Lomira, 2013, p. 459)

Chen and Denoyelles (2013) further develop this concept in their exploration of more specifically what kinds of technology college students utilize. Their investigation found that students used their mobile phone about $58 \%$ of the time for academic use, and revealed that social networking (75\%) and music (71\%) were the most frequent activities using mobile devices. Use of these devices for academic activities such as books (19\%) and reference materials (17\%) quickly declines. Additionally, the study found that freshmen and sophomores tended to 
use small mobile devices in courses more often than juniors and seniors, and males tended to use these devices for academic purposes more than females.

Burston (2011) suggests that MALL, in particular mobile phone usage, is capable of supporting our teaching methodologies, but reinforces that technology can only be as good as the pedagogy (and teacher expertise and creativity) behind it. As teachers, it is important not to assume that students know how to use everything they own as an academic tool; understanding students' mobile practices can help guide instructor development and planning (Dahlstrom, 2012). Today's technology affords the world language learner an opportunity to be selfdirected and engaged with the native speaking world. It is critical, as Burston (2011) points out, for educators to understand the nature of our students' selfdirected use of technology in and outside of language classrooms. Menezes (2011) emphasizes that there are important gaps between what teachers and language learners think studying a second language should be, as well as between the world of language education and the multimodal technology-infused world where our students live when they leave our classrooms. It is risky to infer that increasing the role played by technology in our classrooms will positively impact the language learners' experience, have an advancing effect on their task investment (Norton, 2013) or improve their ideal L2 selves, that is, the idealized image of themselves as language learners that they may have developed over time (Dörnyei \& Ushioda, 2009).

\section{THEORETICAL FRAMEWORK AND RESEARCH QUESTIONS}

In an effort to better understand how technology enhances (or detracts from) our students' opportunities to be more motivated and more successful in their language learning endeavors, faculty at one Mid-Atlantic university sought to identify the relationship between what technological tools the students owned, how they used them, and whether this relationship would yield any conclusion about their commitment to learning a world language.

Within our curriculum, new textbooks that promote e-books and online adaptive technologies, classroom techniques such as the flipped classroom, opportunities for social networking, the use of online chat networks and the use of mobile devices in the classroom required attention to the technology used by our students and whether the addition of these technological tools impacted the 
language learners' experience. In order to inform our practice as world language educators, the following research questions were developed.

a) What technological devices do students in world language classes own?

b) What technological devices do students in world language classes use for their academic activities (specific course content related activities)

c) What technological devices do students in world language classes use for their personal activities?

d) Are there correlations between the type of technological device owned and the types of academic and personal activities students engage in?

Additionally, this research project would allow a comparison of our results to the national, non-field specific research on the use of technology, and can be disseminated to faculty to help inform them for their own classroom. Using a similar constructivist approach to Ducate and Lomicka (2013), a survey was developed to investigate our students' experiences and interactions with their mobile devices.

\section{MeTHODOLOGY}

In order to provide faculty with information about what kind of technology our students use, a pilot survey was developed and the appropriate Institutional Review Board for human participant research approval was obtained. The pilot survey was conducted in a paper format in selected Spanish, French, and Chinese courses. Data from the pilot survey was used to revise and expand the final survey, to be administered online to all students taking world language classes at our institution that following fall semester. While it was expected that the response rate would be reduced in an online, anonymous survey, doing so also disconnected students' responses from specific courses or instructors, and facilitated easier analysis of the survey results. The survey was anonymous, but included demographic information regarding gender, age range, and classification of the participants. In order to facilitate future research, the online survey tool also allowed students to volunteer to participate in a follow-up focus group without revealing their anonymous responses. 
Realities of mobile learning technologies...

\section{SURVEY INSTRUMENT}

In addition to the demographic information, three categories of mobile devices were chosen for inclusion in the survey content: Computer, Smart Phones and Tablets. Participants were asked to rank their use of each device for personal and academic use, using a Likert scale that ranged from One time /Never (1) to More than once a day (5). See Appendix A for excerpts from the survey instrument. Responses regarding the use of tablets were marginal among our respondents and we cannot explore the role of tablets as in depth as for computers and smart phones in this manuscript.

\section{PARTiCipants}

A voluntary response sample of participants was recruited from all students enrolled in world language classes that fall semester. Faculty interested in engaging their students in research provided information about the online survey to their students. Approximately 1000 world language students were reached through e-mail, reminder cards and word of mouth, and 251 valid responses were received, for an estimated response rate of $25 \%$. Following completion of the online survey, a small group of students volunteered to participate in a focus group, which was conducted following the protocol in Costner, Dassier \& Kawamura (2005). These data expand on the quantitative survey results, and reveal additional areas for exploration.

\section{RESUltS AND DisCUSSION}

\section{Survey Demographics}

A total of 259 surveys were completed and 251 were valid; the percentage of valid surveys was 97\%. Demographically, the sample included 43 freshman (17\%), 49 sophomores (19\%), 70 juniors (27\%), 71 seniors (28\%) and 24 students who did not specify a classification. 203 (81\%) respondents were female, and 48 were male (19\%). Comparing these demographics to course rosters, this can be said to be typical of enrollments in language classes. 
Additionally, respondents were primarily between the ages of 18 and $22(82 \%)$, with 21 students (8\%) ranging in age from 23 to 26, and $22(9 \%)$ reporting an age of 27 or older. These are demographics that would be expected from a traditional undergraduate population at our institution.

What technological devices do students in world language classes own?

Nearly all participants (98\%) owned a computer. The majority were PC owners (73\%), and the remainder owned a Mac (26\%). It does appear that our students prefer some portability, as $94 \%$ owned a laptop - with only $15 \%$ owning a desktop computer. Eighty percent $(80 \%)$ of participants owned a smart phone, but surprisingly, only about one fifth of them (22\%) had a tablet. Interestingly, $67 \%$ of respondents stated that they owned both a smart phone and a laptop; only $11 \%$ indicated ownership of a smart phone and a desktop computer.

\section{What technological devices do students in world language classes use for their coursework and personal activities?}

In general, students employ their personal technology for significantly less academic use; this was evident in both computer and smart phone responses. Interestingly enough, despite a large demographic of female respondents 203 (81\%), only $149(73 \%)$ indicate they owned a smart phone. Of the $48(19 \%)$ male respondents only $60 \%$ indicated they owned cell phones ( 29 of the 48 male respondents).

Participants were primarily typical college age ( $88 \%$ were 18 -22 years old) and $69 \%$ (154 of the 223 responses) indicated they owned a smart phone. $80 \%$ of respondents in this category indicated they owned a smart phone. Interestingly, $39 \%$ ( 70 of 178 ) of freshmen and sophomores versus 54\% of juniors and seniors who owned smart phones.

In terms of language studied, participants were asked to provide not only the language they had studied, but also their major. Not surprisingly, the largest percentages of participants were studying Spanish (52\%) along with French (26\%) and Asian languages (Chinese/Japanese 8\%). Other languages studied, can be seen in Figure 1. 


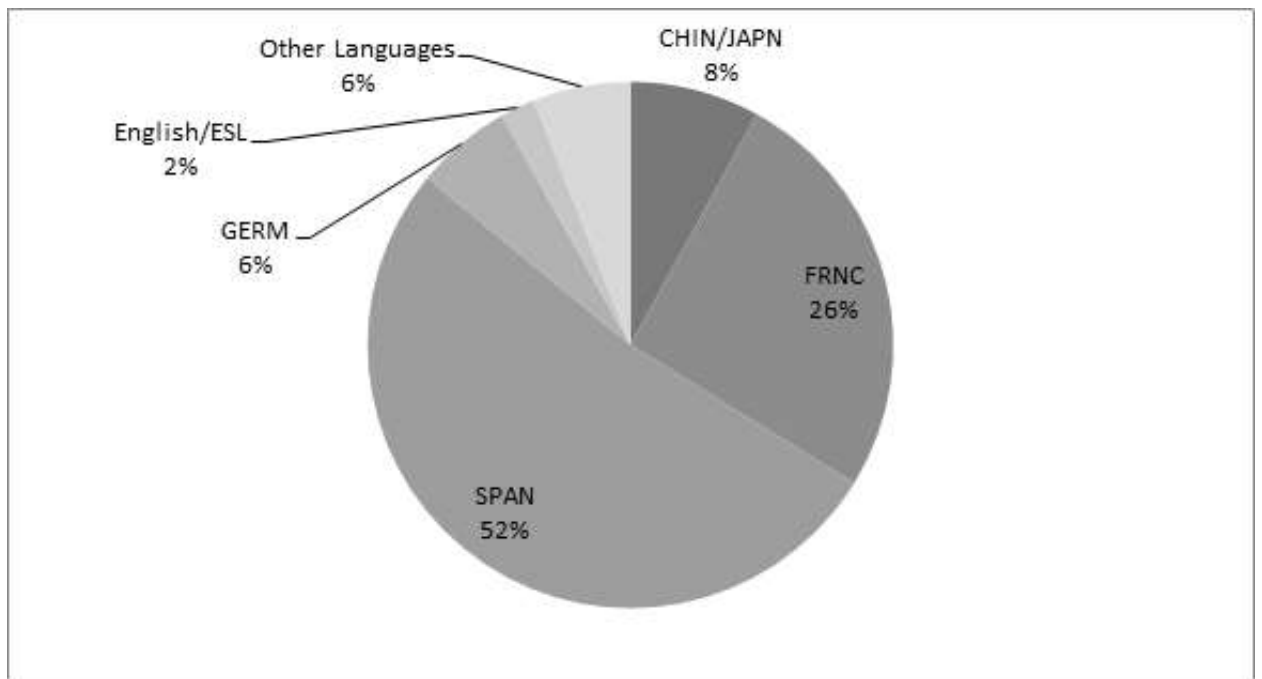

Figure 1. Language Studied.

Next, students were asked to rate how often they use their technology devices for specific academic and personal activities. For example, students were asked how often they used their smart phone to send e-mails, listen to or download music, etc. (See Appendix A for a survey excerpt).

To evaluate these activities, the survey presented students with a Likert scale ranging from one time/never to more than once a day. Students were asked to rank a list of activities indicating how often they use their devices for those specific activities for personal use, and again for academic use.

Table 1

Highest Frequency of responses: computer use-personal

\begin{tabular}{cll}
\hline Rank & Items & Mean \\
\hline 1 & Search engines & 4.28 \\
2 & Social networking & 4.26 \\
3 & Email & 3.94 \\
4 & Instant communication & 3.77 \\
& Downloading/ & \\
5 & listening audio files & 3.68 \\
\hline
\end{tabular}


Table 2

Highest Frequency of responses: computer use-academic

\begin{tabular}{clc}
\hline Rank & \multicolumn{1}{c}{ Items } & Mean \\
\hline 1 & Email & 4.39 \\
2 & Search engines & 3.99 \\
3 & Word processing & 3.77 \\
4 & Reference tools & 3.21 \\
5 & Organizational tools & 2.96 \\
\hline
\end{tabular}

Students reported using e-mail and search technologies most frequently for both academic and personal use. However, one technologybased activity that has grown in recent years is the use of audio recording and online video or chat. Many textbooks now incorporate audio listening activities, online video activities or interactive chat activities using tools such as Blackboard IM. Student's use of audio recording features on their computers ranked significantly lower than other tasks. Students responded indicating that they would only use audio or video recording on their computers $(\mathrm{M}=1.63$ or $\mathrm{M}=1.55$ respectively) for personal use. Their responses were similar for academic use for audio $(\mathrm{M}=1.51)$, for audio/video recording $(\mathrm{M}=1.42)$ and $(\mathrm{M}=1.47)$ for online video chat.

Similarly, students were asked to rank what features they use on their phone for personal and academic use.

Table 3

Highest Frequency of responses for phone: personal use

\begin{tabular}{clc}
\multicolumn{1}{c}{ Rank } & Mean \\
\hline 1 & Instant communication & 4.75 \\
2 & Phone services/calls & 4.31 \\
3 & Social networking & 4.31 \\
4 & Email & 3.94 \\
5 & Search engines & 3.81 \\
\hline
\end{tabular}


Table 4

Highest Frequency of responses for phone: academic use

\begin{tabular}{clc}
\hline Rank & \multicolumn{1}{c}{ Items } & Mean \\
\hline 1 & Email & 3.74 \\
2 & Search engines & 3.42 \\
3 & Organizational tools & 3.11 \\
4 & Accessories & 2.88 \\
5 & Reference tools & 2.76 \\
\hline
\end{tabular}

From these responses, we can see that students tend to use their phones (personally) for instant communication $(\mathrm{M}=4.75)$, phone service and social networking ( $M=4.31$ each), e-mail $(M=3.94)$ and search engine $(M=3.81)$. However, for academic use, students again rate e-mail and search engines as their primary uses. (See Focus group discussion for a possible explanation for this seemingly limited preference).

Additionally, the internet provides language students with access to target language communities, and there are many types of assignments that can be designed using web searches, web quests, etc. In designing our class activities, one activity that might be commonly seen might involve students using a search engine (such as Google or Bing) to locate information on a specific topic. Among students who owned a computer, search engines were ranked highest for personal use, and second highest for academic use, with means of 4.28 and 3.99, respectively. These tools also rose to the top for personal phone use, with means of 3.81 and 3.42 respectively.

Another common assignment may be an online blogging or Facebook kind of assignment. In contrast, students ranked social networking significantly lower for academic use $(\mathrm{M}=2.62)$. Many other commonly used technology-based activities showed a low frequency of use for smart phones: audio recording/editing 1.65, video 1.87 for personal use, and 1.32 video, 1.49 audio and 1.46 for online video chat.

It is important to consider this low frequency of use when planning technology-based activities for our classrooms. The rates may not mean that such activities are inappropriate or undesirable, however, it is important not to assume students are fully proficient or comfortable with that particular technology for academic use. Activities of this nature should also include instructional time and technology support. 
In addition to language studied, participants were asked to provide their major. The top 6 majors are shown in Table 5 below (including ties):

Table 5

Top six majors of participants

\begin{tabular}{lcc}
\hline Major & Number & Percentage \\
\hline Psychology & 30 & $12 \%$ \\
Biology & 20 & $8 \%$ \\
English & 20 & $8 \%$ \\
Hospitality Management & 15 & $6 \%$ \\
Pre-med/chiropractic/dental/Physical Therapy/Vet & 14 & $6 \%$ \\
Sociology & 14 & $6 \%$ \\
\hline
\end{tabular}

Given that the majority of undergraduate students who take languages are required to do as a requirement for their chosen major, it is not surprising that the majority of respondents were not world language majors. As a result, the subset of language majors who completed the survey is a small one.

Table 6

Breakdown by World Language Majors ${ }^{a}$

\begin{tabular}{lcc}
\hline Major & Number & Percentage \\
\hline Spanish & 14 & $6 \%$ \\
Spanish Education & 9 & $4 \%$ \\
Asian Studies & 8 & $3 \%$ \\
\hline
\end{tabular}

a. These are currently the only active majors available in the university

However, it is interesting to note that a review of technology use revealed only minor differences in the top five activities used by language majors, for both computer and smart phone: Language majors included streaming videos as a frequent personal use on their computers $(\mathrm{M}=3.13)$ and included translation tools among their academic uses $(\mathrm{M}=3.26$, while eliminating organizational tools). Language majors also included phone calls under both personal $(\mathrm{M}=$ 4.17) and academic $(\mathrm{M}=2.56)$ uses of their smart phones, and did not include downloading audio files in their personal use, or word processing in their academic use. These findings are similar to students taking language classes as a requirement for a non-language major. 


\section{Are there correlations between the type of technological device owned and the types of activities students engage in?}

In a further effort to compare computer use for personal versus academic purposes, a paired T-test was conducted to attempt to correlate how students used their computers for personal and academic purposes. Results indicated that computers were more frequently used for personal use $(M=2.89, S D=.61)$ than for academic use $(M=2.24, S D=.54)$, and the difference was statistically significant, $\mathrm{t}(218)=17.56, p=.000$. This confirmed the initial findings of our first research question.

Similarly, a paired T-test was conducted to analyze how students used their smart phones for personal and academic purposes. Results indicated that smart phones were more frequently used for personal use $(M=2.91, S D=.70)$ than for academic use $(M=2.11, S D=.74)$, and difference was statistically significant, $\mathrm{t}$ $(155)=16.55, p=.000$.

The figures below show that students tend to use their technology slightly more frequently for personal use; while they use specific technology as noted in the highest frequency tables above, the vast majority of their technology use is associated with personal activities. Notably, students showed the largest separation between making phone calls, social networking and downloading/streaming video. 


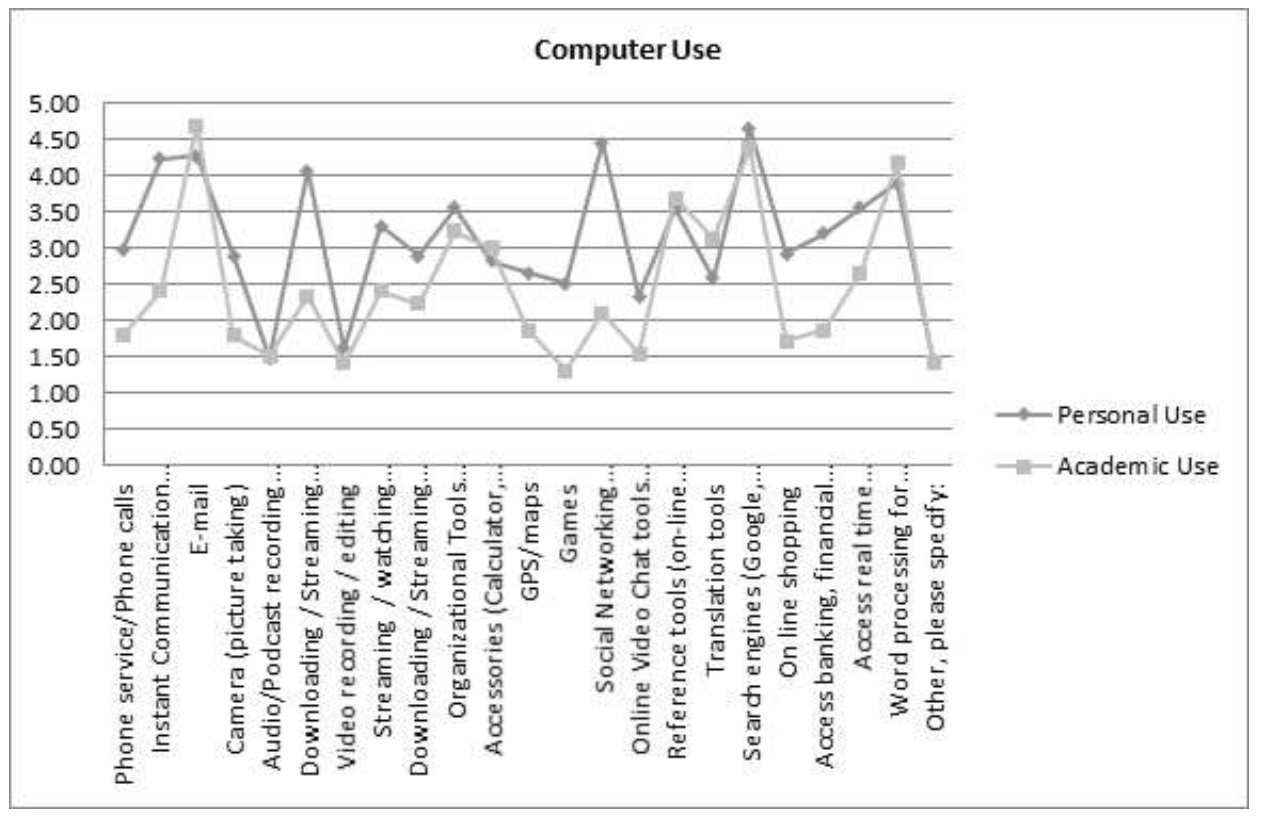

Figure 2. Comparison of computer use for personal versus academic activities.

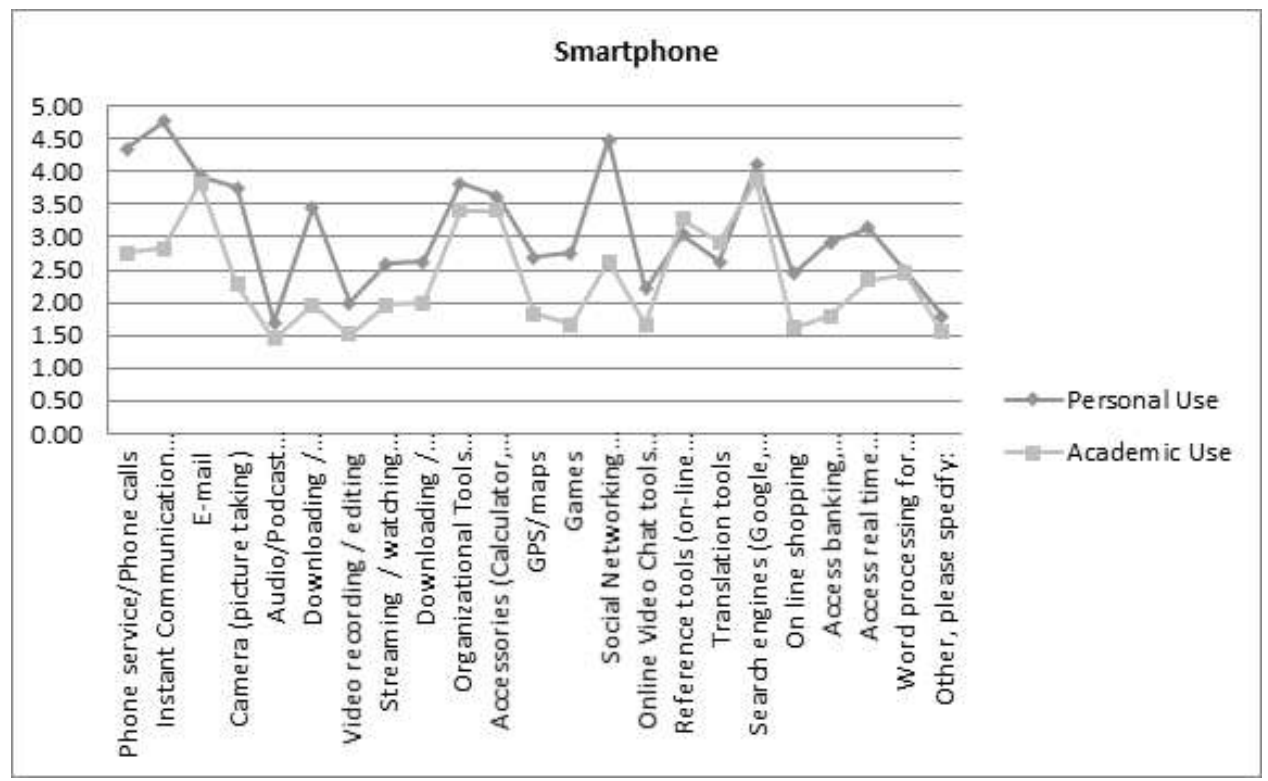

Figure 3. Comparison of smart phone use for personal versus academic activities 


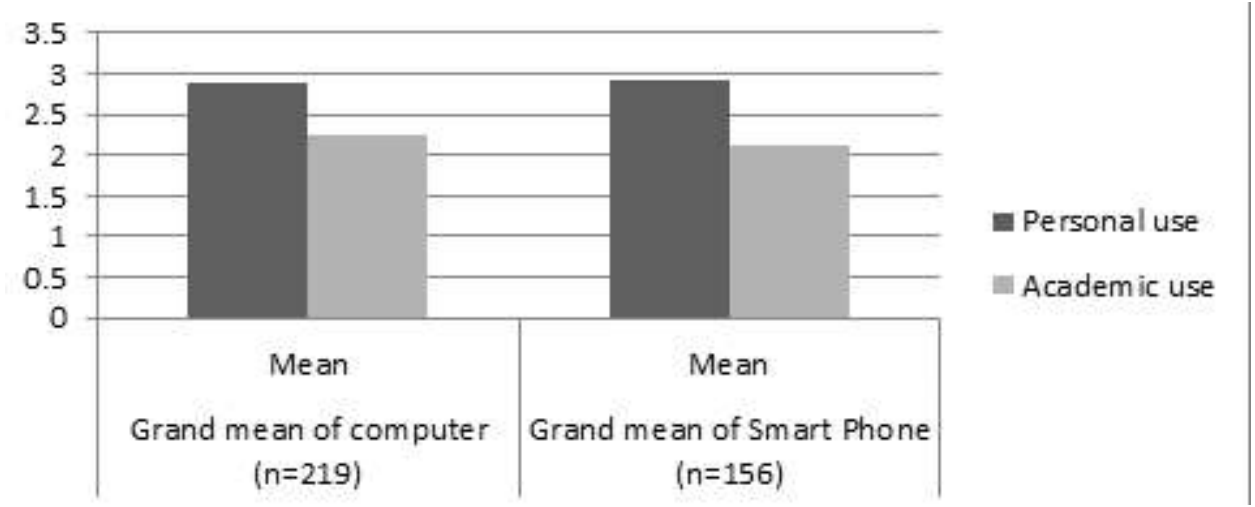

Figure 4. Overall personal versus academic use for computers and smart phones $($ max possible mean $=5)$.

\section{FocUs GrouP}

Alerted by informal discussions with students, it seemed to us that there may be more issues beyond what the previous descriptive statistics were telling us. We needed to explore and discover potentially new topics, but also to investigate deeper the ones previously mentioned by directing our attention to only students engaged in world language study (versus national research). We organized a focus group because only this data collection tool would "bring both a rich explanatory context and a greater depth of understanding" (Costner, Dassier, \& Kawamura, 2005).

A focus group guide including the usual five types of questions (Warmup/Opening, Introductory, Transition, Key, and Summary questions) was developed and accepted by the university Internal Review Board. Next, a random sample of 39 students who had expressed interest in further participation received a generic invitation by email: The target was to invite the first eleven students who could fit the proposed date and time in their schedules. Among the 11 students who were invited, nine students were present when we collected the data. The focus group was moderated by one of the researchers in an atmosphere that was pleasant and relaxed despite being audio recorded. There were three males and six females in this group including one student enrolled in a Chinese class, one student enrolled in Japanese, one student enrolled in German, 3 students enrolled in French, and 3 students enrolled in Spanish, including one Spanish Education major. 
As the recording was being systematically coded, it was noted how quickly significant topics began to emerge in the focus group protocol. For instance, one of the introductory questions, which are designed to refocus the participants' biographical accounts on the issue of technology use after introducing themselves (see Costner, Dassier, \& Kawamura, 2005) asked them to simply describe the type of technological devices they owned. While all nine participants owned a laptop and a smart phone, only three of them owned a tablet. This proportion roughly echoes what the researchers had found about the population that responded to the survey. Equally, it became evident that, while the laptop could be considered the innovation for previous generations, our respondents had learned to communicate and interact with technology through smart phones and gaming consoles: many of them had owned a smart phone since they were in third grade or shortly after, and at least two of our participants had been using their gaming consoles to communicate with distant friends or relatives. The tone was set early: these were the digital natives as defined by the current literature.

The participants initiated the transition without prompting as one of the three males initiated the following topic: "I use my phone more than my laptop." The moderator tried to redirect the topic and asked the participants to evaluate whether they used their smart phones more for personal use or for any reason linked to their studies (i.e. academic use). Their evaluation of their smart phone use was rather cut and dry: if you were to remove the electronic mail function from the smart phones, they would use them almost exclusively for personal purposes. Indeed, when further prompted to search for exceptions to that rule, participants seem to have only anecdotal accounts (one professor had experimented with a polling, anonymous instantaneous feedback application; recording podcasts for a French class; occasional use of applications found online for study aids; quick "googling" of terms). The smart phone is small, convenient, and used mostly, as stated by one of our male French learners, for "content consumption" (news, music, video clips, etc.) and for personal communication (phone, texting, social networks).

In contrast, it seemed that the laptop computer was meant to be more for content production. With the exception of one of the French-learning students who claimed doing everything on her smart phone (even write papers), most of our participants agreed with the following statement by the German student:

"I just like it bigger; ... when I'm studying in the library and it is between the cell phone or the laptop, I'll study on my laptop... but if I'm walking 
or I'm somewhere where I cannot have my laptop, I'll use my cell phone."

If one needed to be convinced of the fact that the smart phone is for these digital natives more personal than the laptop, it should be noted that the participants brought up the issue of which of the two devices was the most precious to them and all but one of them chose their smart phones over their laptops. There was, however, one communication function at least for which the laptop outranked the smart phone: Video-conferencing or video chatting on a smart phone is awkward. One of the participants illustrated the argument as follows:

"I hate [video chatting] on my phone; I hate to have to keep my hand up (echoes from the group: "Yeah!"), like it just makes awkward angles.

And I talk with my hands, so if I talk to a person... (giggles)."

Now that this group seemed to have set the parameters of their technological device preferences, it did not take much prompting from the moderator to have them discuss how they felt about using technology in their course work. The first two participants selected the next big topic and set the tone. The first one took the floor and stated quite defiantly: "I think that some professors think that, since we like Facebook and stuff like that, we're automatically going to use that app and it's gonna be 'awesome' (sarcastic tone)... and we don't like it!' She barely had a chance to finish her thought when her neighbor explained:

"For a class, a professor wants you to create a Twitter account and you follow them or their Twitter account or Tumblr... Sometimes I find myself logging on Twitter... and I know exactly what I'm gonna do on Twitter, and it has nothing to do with schoolwork because Twitter, Tumblr, Facebook are more social (pronounced emphatically) networking compared to academic networking sites. And I have done that in some class where I know I'm going to create that account for that class, and it is going to distract me more than it is going to help me."

This issue was the most robust one: Given that the smart phone was primarily personal and content consumption, and the laptop was mostly academic and content production, our colleagues' efforts to merge personal and academic worlds in assignments to be done on social media sites created a lot of resentments from all our language learners, regardless of gender or language learned. Very typically, one of our Spanish learners explained: 
"I don't like to get an assignment on Facebook because I look at Facebook and Twitter as, like, my (emphatically) free time; like I'm taking a time-out to, maybe, catch up, talk with my family in Italy, talk with friends who go to different universities and see what's going on... and if I have to go on this site to do an academic assignment, I look at it as they are intruding on my personal time."

To which her French-learning neighbor added:

"It's the idea of turning something we try to use for fun into not fun (emphatically)... we use Facebook to escape from academics, so merging the two would not have good consequences."

As mixing their personal and academic arenas in social media site assignments elicited a resounding rejection, participants were asked to reflect on positive applications of technology for their coursework. The sole language major present during the focus group interview broached the topic of using video conferencing applications or websites to speak with native speakers. Quite enthusiastically, she stated:

"I think it's a great thing! [It brings new] opportunities for students who want to develop their proficiency without having to find someone on campus; and you can make it not so personal so they cannot see you --it can literally just be voice-- and I think it's just a great way of doing it on your time and not have to worry about people around you.... It is important to speak with Native Speakers, because they can correct your pronunciation."

The statement came from a highly motivated, highly invested (Norton, 2013) language major who needs to reach the Advanced-Low proficiency in speaking and writing to complete her degree and become a certified Spanish teacher. One of the participants seated to her left, who is just learning French to complete his language requirement and has to speak with French native speakers by video chat twice a semester, tempered a little bit this optimistic picture:

"I like [video chatting], but because I get awkward and a little nervous sometimes when I speak to people, I always spend the first 10 minutes going like 'I'm sorry, I can't speak French...' and they're like 'yes, you're fine...' and when I'm past that, I'm fine. But it's like I have to force myself to get on there because I'm thinking 'get on there! get on there!' but it's never something I want to do, I'll be honest." 
Therefore the success of such activities seems to depend on more than just the availability of the technological means and the respect of the personal/academic demarcation line as suggested by Dassier (2013).

It could be said that most participants' notions of how technology could enhance their language learning experience were a bit unimaginative and in some cases quite symptomatic of their anxiety about speaking publicly a second language that they have not mastered "perfectly" and thus exposing their faults to their peers. According to at least five of our participants, one of the spontaneous positive additions that technology can make to the learning process was the use of online anonymous polling applications or websites. Learners seemed to appreciate the cloak of anonymity provided by such devices. One of the participants even mentioned that the use of such devices in one of her lecture classes was her "favorite," and when prompted to explain why, she simply stated: "You won't be judged [for your answers]; but it brings discussions that can be very important... [Otherwise] the professor is like 'oh yeah, there is no question ...' There are questions, but people are just too insecure to voice them." When further prompted to explain how these anonymous polling devices could be used in a world language class, she seemed to struggle a bit, then proposed to use them for grammar reviews. The other participants remained silent.

Concerns about anonymity and the line between personal and academic domains are not the only way in which these participants realized the fundamentally different nature of a world language class. When asked to elaborate on how technology could further enhance their world language learning experience, initial spontaneous answers mentioned the usual reference websites and online resources... but the same learners quickly reversed their opinion by bringing up two important topics. First, the resources that the instructor finds relevant may not be appealing to students:

"...the professor gives us a lot of online resources; the problem is that the resources are so boring... I have been looking for children's resources because the adult versions are so boring... [the professor] encourages us to practice [with the online resources], but we don't want to because it is so boring."

Second, the availability at your fingertips of reference tools may not help the less invested learners: "I think that's a way technology can harm (emphatically) our learning, I'll be the first one to admit it. I have such a hard time remembering vocabulary... no deep processing, just recall!" At the end of the day, the 
participants in our focus group not only proved that the use of technology during the language learning experience is a complex phenomenon that needs to respect some of their imperatives (not crossing that line between their personal and academic worlds), but also that instructors may have to force them to move away from more familiar and comfortable uses of the technological devices they currently own.

\section{CONCLUSIONS AND SUGGESTIONS FOR FUTURE RESEARCH}

The details uncovered by our research initiative provide a glimpse into the use of technology in world language learning by our students. Three salient points can be drawn from the data in this project.

1. When comparing our results to the general (non-discipline specific) national research on technology use, our responses align with national trends over time, as shown in Figure 5:

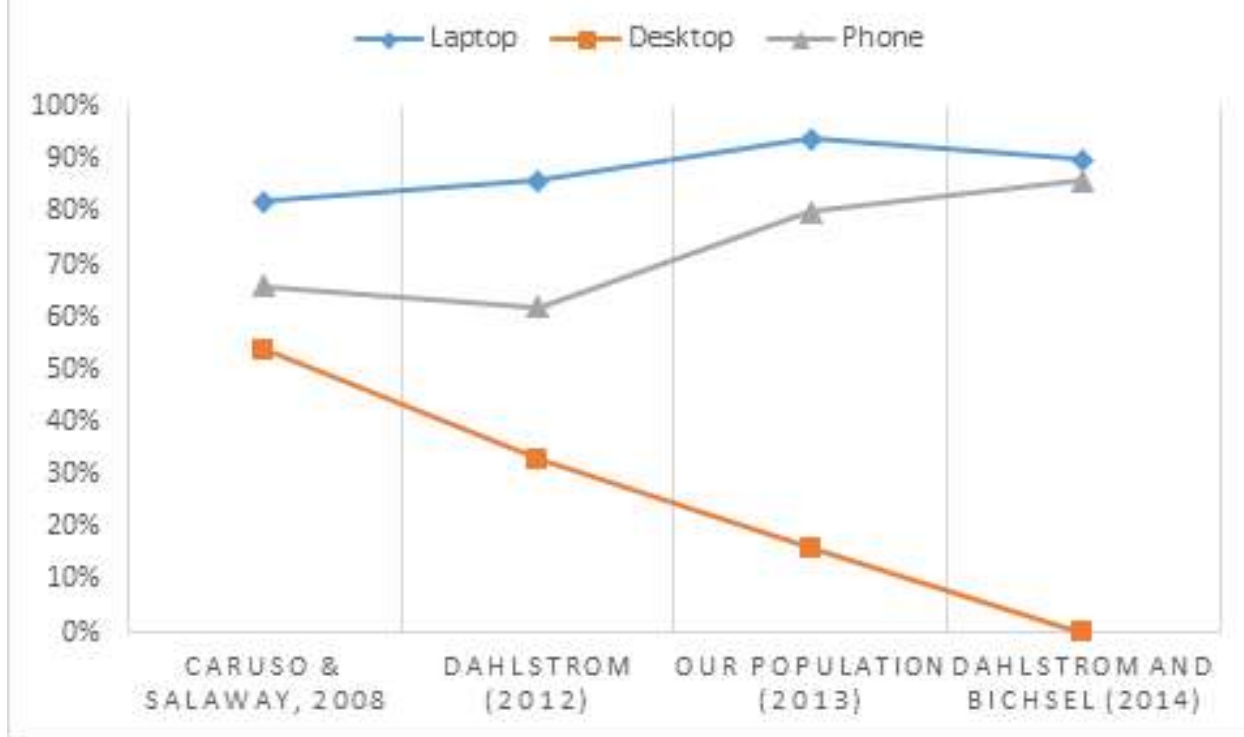

Figure 5. Comparison of technology ownership over time.

It is interesting to note the fact that there are so many similarities to the national, non-discipline specific research. It is possible that the technology in our curriculum is not as transparent to students as we would hope. It is also possible 
that some instructors are using technology just to use it; it represents for them a new "methodology."

2. Dahlstrom (2012) found that "When it comes to device preferences, the usability afforded by the larger screens and keyboards of laptops trumps the portability offered by tablets (p.24)." This is also evident in our research. One interesting result of our investigation was the very low percentage of respondents who owned tablet devices (22\%) as compared to laptop ownership, and our focus group participants expressed a strong desire to use the laptop when they wanted a larger screen. Many world language (and other) textbook publishers have begun to extol the virtues of the e-textbook versus a paper textbook. However, if the majority of students in our world language classes don't own or use the appropriate mobile technology, choosing a textbook platform (or other online materials) that relies heavily on that technology is illogical.

Furthermore, as Blake (2013) and Burston (2011) caution, it is important to focus not on the latest and greatest technology, but rather pedagogy; the technology must be the medium not the methodology. Most current world language textbooks use some form of online components. At our institution, this online work is a required course component, and presumes that students have access and expertise in that technology. Our survey and focus groups data reveals that students may have access, but faculty should not make assumptions that students like, and are knowledgeable in using all technology platforms.

Students prefer different platforms for different purposes and audiences and tend to use social networks for interacting with friends more than for academic communication (Dahlstrom, 2012). Similar to Ducate and Lomicka (2013) world language students in our population affirm that they use their devices for a variety of activities. More specifically, students in our population tend to prefer their smart phones for personal activities, and their computers for academic activities. In both the quantitative, descriptive data and in the focus group, students mentioned an important "line of demarcation" between their academic work and their personal work. With the increase in the accessibility of smart phone and other mobile technologies, it is important to be aware of this distinction on behalf of our students. Presuming that an assignment will be wellreceived and effective simply because it employs our student's devices is a risky premise.

3. Finally when questioned about the role that they would want technology to take in their world language learning experience, it should be noted that our 
students are mostly unimaginative and somewhat confused about the nature of communicative language teaching. They want technology to further separate their academic life from their personal life, indicating their lack of investment (Norton, 2013) in the language learning task. Students want to use technology to allow them to remain anonymous while making the necessary errors to progress in their second language. When prompted to define how that could occur, they fall back on a notion of language that is reduced to its grammatical properties, indicating that they do not understand the unique nature of learning to communicate in a different language. Furthermore, their L2 self (Dörnyei \& Ushioda 2009) is poorly developed if at all; the imperative remains for them not to be seen or heard making errors in public.

These findings demonstrate forcefully that technology must not be considered a methodology and that each world language teacher needs to define his/her own practice of how technology can assist learners in developing that ideal L2 self. It is the capacity of the learners to conceive themselves as proficient speakers of the target language that will support their investment in all language learning endeavors. What could aid learners in understanding the unique nature of world language learning is not different or new technological tools, but rather a pedagogical and methodological approach that first and foremost allows the student to become a self-invested and motivated language learner.

\section{LIMITATIONS AND SUGGESTIONS FOR FUTURE RESEARCH.}

All research has biases and limitations and the present study is no exception. While our primary purpose was to inform classroom practice, our sample is a voluntary one, and as such is naturally biased. The sample used in this study limits the generalizability of our results, in particular because it is drawn from one specific institution. The survey was also conducted online, which may have had an effect on sample size and responses. For example, the small number of language majors who responded to the survey may have been influenced by the course levels of students who chose to respond to the survey, as lower level courses would be unlikely to contain large numbers of language majors.

Additionally, the data of our study were from one public university with about 15,000 students, Device ownership might be different from that of private universities. For example, some liberal arts colleges gave each of their students a 
laptop and/or an iPad, or students have more disposable income to purchase technological devices.

Finally, the survey items were designed to compare and contrast between academic and personal use, some items were too general and not specific to language learning. A potential expansion of this research could include expansion of the categories to include items such as what textbook components students may be accessing, or expanding the study beyond one institution, and drawing comparisons between and across institutions in order to form a profile of world language students' use of technology. 


\begin{abstract}
About The Authors
Christina Huhn earned her doctorate in Foreign Language Education with secondary studies in Technology from Purdue University. Her experience includes work in a wide variety of areas, including second language writing, beginning language learners, and technology.. She is also a member at large of the Pennsylvania State Modern Language Association and is currently president of the Appalachian Professional Language Educators' Society (APPLES).

Jean-Louis Dassier earned a bachelor's and master's degree at the Universite de Paris VIII, majoring in English and American Civilization and Culture. In addition, he received a M.A. from the University of Delaware in French Literature and Applied Linguistics, and earned his Ph.D. in Foreign and Second Language of Education at Ohio State University.

Shijuan Liu received her doctorate in Instructional Systems Technology from School of Education of Indiana University at Bloomington, and has been involved with teaching Chinese as a foreign/second language since 1995. She serves as the column editor for the Journal of Technology and Chinese Language Teaching, and on the editorial board of several peer-reviewed journals. Her current research focuses on Chinese language pedagogy and application of emerging technologies in education.
\end{abstract}


Realities of mobile learning technologies...

\section{REFERENCES}

Brown, J. S. (2001). Learning in the digital age. In The Internet and the university: Forum, 71-72.

Burston, J. (2011). Exploiting the pedagogical potential of MALL. Proceedings of Mobile Learning as the future of education.

Burston, J. (2014a). The reality of MALL project implementations: Still on the fringes. CALICO Journal, 31(1), 103-125.. Retrievable from https://www.calico.org.

Burston, J. (2014b). A survey of MALL curriculum integration: What the published research doesn't tell. CALICO Journal, 31(1), 303-322 Retrievable from https://www.calico.org.

Caruso, J. B., \& Salaway, G. (2008). The ECAR study of undergraduate students and information technology. EDUCAUSE. Retrieved June 1, 2015, from http://net.educause.edu/ir/library/pdf/EKF/ekf0808.pdf

Chen, B., \& Denoyelles, A. (2013). Exploring Students' Mobile Learning Practices in Higher Education. Educause Review Online.

Chinnery, G. M. (2006). Going to the MALL: Mobile assisted language learning. Language Learning \& Technology, 10, 9-16 Retrieved June 1, 2015, from http://lit.msu.edu/vol10num1/emerging/default.html.

Costner, K.M., Dassier, \& Kawamura, H. (2005). Using focus groups effectively. In D. W. Birckbichler, (Ed.), Evaluating Foreign Language Programs: Content; Context; and Change. Columbus, OH: OSU Foreign Language Publications.

Dahlstrom, E., and Bichsel, J. ECAR Study of Undergraduate Students and Information Technology, 2014. Research report. Louisville, CO: ECAR, October 2014. Retrieved March 13, 2015, from

http://www.educause.edu/library/resources/study-students-andinformation-technology-2014.

Dahlstrom, E. ECAR Study of Undergraduate Students and Information Technology, 2012 (Research Report). Louisville, CO: EDUCAUSE Center for Applied Research, September 2012, Retrieved June 1, 2015, 
Huhn, Dossier, \& Liu

from http:/www.educause.edu/library/resources/ecar-studyundergraduate-students-and-information-technology-2012.

Dassier, JL, (2013, October). Building Proficiency through Social Media: A preliminary report. Paper presented at the annual meeting of Pennsylvania State Modern Language Association Fall Conference, Pittsburgh, PA.

Dörnyei, Z., \& Ushioda, E. (Eds.). (2009). Motivation, language identity and the L2 self (Vol. 36). Multilingual Matters.

Ducate, L., \& Lomicka, L. (2013). Going mobile: Language learning with an iPod touch in intermediate French and German classes. Foreign Language Annals, 46(3), 445-468.

Kennedy, G. E., Judd, T. S., Churchward, A., Gray, K., \& Krause, K. L. (2008). First year students' experiences with technology: Are they really digital natives? Australasian journal of educational technology, 24(1).

Kukulska-Hulme, A. and Shield, L. (2008). An overview of mobile assisted language learning: From content delivery to supported collaboration and interaction. ReCALL, 20(3), pp. 271-289.

Lai, C. (2013). A framework for developing self-directed technology use for language learning. Language Learning \& Technology, 17(2), 100-122. Retrieved from http://ltt.msu.edu/issues/june2013/lai.pdf.

Menezes, V. (2011). Affordances for language learning beyond the classroom. In Benson, P., \& Reiders, H. (eds). Beyond the Language Classroom. The Theory and Practice of Informal Language Learning and Teaching. 5971. Basingstoke: Palgrave Macmillan,

Norton, B. (2013). Identity and Language Learning; Extending the Conversation (2nd Edition). Bristol, United Kingdom: Multilingual Matters.

Prensky, M. (2001). Digital natives, digital immigrants part 1. On the horizon, $9(5), 1-6$.

Salaberry, M.R. (2001). The use of technology for second language learning and teaching: A retrospective. The Modern Language Journal, 85(i), 39-56. 
Realities of mobile learning technologies...

\title{
APPENDIX A
}

\author{
Survey Excerpt
}

\begin{tabular}{|c|c|c|c|c|c|c|c|c|c|c|}
\hline & \multicolumn{5}{|c|}{ Personal Use } & \multicolumn{5}{|c|}{ Academic Use } \\
\hline & $\begin{array}{c}\text { One } \\
\text { time/never }\end{array}$ & Occasionally & $\begin{array}{c}\text { At } \\
\text { least } \\
\text { once } \\
\text { a } \\
\text { week }\end{array}$ & Daily & $\begin{array}{c}\text { More } \\
\text { than } \\
\text { once } \\
\text { a } \\
\text { day }\end{array}$ & $\begin{array}{l}\text { One } \\
\text { time } / \\
\text { never }\end{array}$ & Occasionally & $\begin{array}{c}\text { At } \\
\text { least } \\
\text { once } \\
\text { a } \\
\text { week }\end{array}$ & Daily & $\begin{array}{c}\text { More } \\
\text { than } \\
\text { once } \\
\text { a } \\
\text { day }\end{array}$ \\
\hline $\begin{array}{l}\text { Phone service/Phone } \\
\text { calls }\end{array}$ & ○ & ○ & ○ & O & O & O & ○ & ○ & ○ & ○ \\
\hline $\begin{array}{l}\text { Instant Communication } \\
\text { (Texting, instant } \\
\text { messaging) }\end{array}$ & ○ & ○ & O & O & O & ○ & ○ & ○ & O & ○ \\
\hline E-mail & $\odot$ & $\odot$ & $\bigcirc$ & O & O & ○ & $\odot$ & O & O & O \\
\hline Camera (picture taking) & ○ & ○ & 0 & O & O & ○ & $\odot$ & ○ & O & ○ \\
\hline $\begin{array}{l}\text { Audio/Podcast recording } \\
\text { and editing }\end{array}$ & ○ & ○ & ○ & O & O & ○ & ○ & ○ & O & ○ \\
\hline $\begin{array}{l}\text { Downloading / Streaming } \\
\text { / listening to music (or } \\
\text { other audio files) }\end{array}$ & ○ & ○ & 0 & O & O & ○ & $\odot$ & ○ & 0 & ○ \\
\hline Video recording / editing & ○ & O & 0 & O & O & O & O & O & 0 & O \\
\hline $\begin{array}{l}\text { Streaming / watching } \\
\text { videos or movies }\end{array}$ & ○ & ○ & ○ & 0 & O & ○ & ○ & 0 & 0 & ○ \\
\hline
\end{tabular}

(Note: the same layout was used for computer, phone and tablet questions) 